\title{
Hour Times Microgram per Milliliter per Milligram
}

National Cancer Institute

\section{Source}

National Cancer Institute. Hour Times Microgram per Milliliter per Milligram. NCI

Thesaurus. Code C85617.

Hours times micrograms per milliliter, divided by milligram. 